\title{
Dynamics of Push and Pull Factors of Migrant Workers in Developing Countries: The Case of Indonesian Workers in Malaysia
}

\author{
*Fariastuti Djafar, Mohd Khairul Hisyam Hassan \\ Universiti Malaysia Sarawak (UNIMAS), Malaysia \\ *dfariastuti@feb.unimas.my
}

\begin{abstract}
Low income and high unemployment in labour sending countries and high income and low unemployment in labour receiving countries are frequently justified as push and pull factors of migrant workers, respectively. Indonesia is the main labour-exporting country to Malaysia but the studies on the push factors in Indonesia and the pull factors in Malaysia are very limited. This paper has three objectives. The first objective is to examine the long-run relationship among income and unemployment in Indonesia and Malaysia and the Indonesian migrant workers in Malaysia. This is followed by examining the causality between the variables in the second objective, and the extent to which income and unemployment in Indonesia and Malaysia determine the Indonesian migrant workers in Malaysia in the third objective. Time series data were employed and analysed by utilizing the Vector Autoregressive (VAR) framework. The findings show a long-run relationship among income and unemployment in Indonesia and Malaysia and the Indonesian migrant workers in Malaysia. Only unidirectional causality is found in the long-run, which is from income and unemployment in Indonesia and Malaysia to Indonesian migrant workers in Malaysia. The findings also show that the Indonesian migrant workers in Malaysia are significantly determined by income and unemployment, positively in the case of Indonesia, and negatively, in Malaysia.
\end{abstract}

Keywords: Indonesia, Malaysia, Migrant Workers, Income, Unemployment

\section{Introduction}

Many factors determine the supply of international migrant workers, which are grouped into factors in home countries (push factors), factors in host countries (pull factors) and a combination of these two factors. To date, empirical findings on the studies of push and pull factors of migration are mixed indicating the theories used in explaining these factors have not been solid. For instance, Jennisen (2003) found the positive effect of income both in home and host countries on migration while Ahmad et al. (2008) reported the negative effect of income in the home country on migration. The studies on push and pull factors of migration also tend to concentrate in developed countries. This study attempts to contribute to the debate especially on the use of neo-classical economic theory and dual labour market theory on migration. The focus on Indonesian migrant workers in Malaysia as a research object will also enrich the studies of migration since both Indonesia and Malaysia are developing countries in which Indonesia is still a lower middle income country while Malaysia is an upper middle income country. Low income and job scarcity in Indonesia and conversely, high income and a high demand for low-skilled workers in Malaysia, are popular reasons for the high supply of Indonesian migrant workers to Malaysia. However, an empirical study at the aggregate level on this issue especially which used the Vector Autoregressive (VAR) framework has not been conducted, thus far. Said et al. (n.d.) had studied this issue but applied unemployment in Indonesia as a push factor and income per capita in Malaysia as a pull factor of Indonesian migrant workers in Malaysia. They applied the traditional regression approach instead of the VAR framework. Thus they failed to detect whether their regression results were spurious or not. Nevertheless, they reported that the effect of unemployment in Indonesia and income per capita in Malaysia on Indonesian migrant workers in Malaysia are both positive and significant.

The previous studies on Indonesian migrant workers in Malaysia mainly used a micro approach. These studies, among others, include those conducted by Nasution (2000) on the construction sector; Mantra (2000) on migration from East Flores, West Lombok, and Bawean Island; Widyawati (2008) on an image of the Indonesian migrant workers in the Malaysian media; Wu (2006) on remittance from the Acehnese 
migrants; IOM (2010) on remittance; Mei (2006) on reasons for migration; Yusuf (2008) on occupational mobility among the Acehnese migrants; and Kassim (2000) on settlement. This study has three objectives. The first objective is to examine the long-run relationship among income and unemployment in Indonesia and Malaysia and the Indonesian migrant workers in Malaysia. The second objective is to examine the causality between income and unemployment in Indonesia and Malaysia and the Indonesian migrant workers in Malaysia. Finally, the third objective of this paper is to examine the extent to which income and unemployment in Indonesia and Malaysia determine the Indonesian migrant workers in Malaysia. This paper discusses an overview of the Indonesian migrant workers in the next section, followed by a literature review and methodology in the third and fourth sections, respectively. The fifth section presents the research findings and discussion while the conclusion is presented in the last section.

Overview of Indonesian Migrant Workers in Malaysia: Malaysia is the second most important destination country for Indonesian migrant workers after Saudi Arabia. By 2010, around 23 per cent of the total number of Indonesian migrant workers was working in Malaysia compared to 40 per cent who were working in Saudi Arabia (BPN2TKI, 2012). Malaysia is the closest neighbouring country to Indonesia. The two countries share land and sea borders, have the same major religion (Islam) as well as similarities in language and culture. The Indonesians living in the common border areas of Indonesia and Malaysia rely heavily on Malaysia for their living because accessibility to Malaysia is much easier compared to accessibility to cities in Indonesia. The Malaysian Government classifies migrant workers into foreign workers and expatriate* The foreign workers are those who have a salary of less than RM3, 000 per month while the workers with a higher salary are expatriates (Kanapathy, 2008). Although the number of foreign workers in Malaysia tends to fluctuate, Indonesia continuously shares the largest proportion of foreign workers (more than 50 per cent in 2000, 2005 and 2010, respectively) (Table 1) in Malaysia. This share declined from 75 per cent in 2000 to 51 per cent in 2010 and was compensated by the increasing share of foreign workers from other countries. These workers do not include those who work illegally. The latest programme concerning illegal foreign workers in Malaysia under the Comprehensive Legalization Programme for Illegal Immigrants (6P programme) recorded around 500,000 illegal workers of which61 per cent were from Indonesia (Malaysian Digest, 2012). The number of illegal foreign workers could be much higher since not all of them were covered by the 6P programme and the supply of Indonesian migrant workers to Malaysia seems to continue.

Table 1: Foreign Workers in Malaysia by Main Country of Origin, 2000, 2005 and 2010

\begin{tabular}{lllllll}
\hline Country & $\begin{array}{l}\mathbf{2 0 0 0} \\
\text { Total }\end{array}$ & $\mathbf{0}$ & $\begin{array}{l}\mathbf{2 0 0 5}^{*} \\
\text { Total }\end{array}$ & $\mathbf{\%}$ & $\begin{array}{l}\text { 2010** } \\
\text { Total }\end{array}$ & $\mathbf{\%}$ \\
\hline Indonesia & 603,453 & 74.8 & $1,211,584$ & 66.7 & 918,000 & 50.9 \\
Bangladesh & 158,149 & 19.6 & 55,364 & 3 & 310000 & 17.2 \\
Thailand & 2,335 & 0.2 & 5,751 & 0.3 & 15,000 & 0.8 \\
Philippines & 14,651 & 1.8 & 21,735 & 1.2 & 26,000 & 1.4 \\
Pakistan & 3,101 & 0.3 & 13,297 & 0.7 & 21,000 & 1.2 \\
Others & 25,407 & 3.1 & 507,507 & 28 & 513,200 & 28.5 \\
Total & 807,192 & 100 & $1,815,310$ & 100 & $1,803,200$ & 100 \\
Source: * Ministry of Home Affairs (n.d.) and **Ministry of Home Affairs (n.d.) cited in Ahmad (2012).
\end{tabular}

Indonesian migrant workers were mainly in the construction, manufacturing, plantation and service sectors (Table 2). The distribution of Indonesian migrant workers by sector fluctuated because of the ease of quitting from, and entry into a job. Above all, the largest number of Indonesian migrant workers was in the plantation sector while the smallest number was in the service sector including maids. Throughout the years, more than 30 per cent of the Indonesians were working in the plantation sector, except in 1997. Meanwhile the share of Indonesian migrant workers in the service sector declined sharply from 17 per cent in 1997 to 5 per cent or less in 2001 onwards.

\footnotetext{
* Unless otherwise indicated, in this study migrant workers refer to the foreign workers.
} 
Table 2: Foreign Workers from Indonesia by Sector, Malaysia, 1997-2005

\begin{tabular}{llllll}
\hline Year & Construction & Manufacturing & Plantation & Services & Total (\%) \\
\hline 1997 & 45 & 18 & 21 & 17 & 100 \\
1998 & 26 & 30 & 34 & 11 & 100 \\
1999 & 16 & 40 & 37 & 7 & 100 \\
2000 & 15 & 43 & 36 & 6 & 100 \\
2001 & 9 & 39 & 47 & 5 & 100 \\
2002 & 19 & 28 & 49 & 4 & 100 \\
2003 & 42 & 21 & 34 & 4 & 100 \\
2004 & 38 & 24 & 35 & 3 & 100 \\
2005 & 26 & 24 & 44 & 5 & 100 \\
\hline
\end{tabular}

Source: Computed based on the data from Department of Immigration (n.d.) cited in Said et al (n.d.).

Various issues have arisen regarding the Indonesian migrant workers, especially maids, which has created some tensions in the relationship between Indonesia and Malaysia. The latest issue concerns an illegal advertisement by an agent in Kuala Lumpur saying that the Indonesian maids are on sale. The Indonesian Government even stopped sending maids to Malaysia temporarily due to the incidents of non-payment of wages and ill-treatment by employers. The Indonesian Government also proposed to the Malaysian Government a minimum wage and required one domestic task only for each maid. However, this issue was not responded to well by the Malaysian costumers. Regardless of the policies of the Indonesian Government towards the Indonesian migrant workers, workers from Indonesia continue to migrate for employment to Malaysia thereby indicating a strong demand for foreign workers in Malaysia.

\section{Literature Review}

According to neo-classical economic theory international labour migration is due to different labour markets in the different countries. Based on this theory, labour from countries that have a low income and high unemployment will migrate to countries that have a higher income and lower rate of unemployment (Maseey et al., 1993). Jennisen (2003), in her study often labour sending countries and seven labour receiving countries in Western Europe, concluded that Gross Domestic Product (GDP) per capita representing wage had a positive effect while unemployment had a negative effect on net international migration. Her findings indicate that the effect of GDP per capita and unemployment on international migration is similar between the host and home countries even though the effect is not necessarily significant. The positive effect of income in the host countries on immigration is also supported by other studies. By utilizing the covariance model, Karemera et al. (2000) reported a positive significant effect of income in the United States of America (USA) and Canada on international labour migration. However, only income significantly affects labour migration in the USA. Meanwhile, by using the VAR framework, Islam (2007) found a positive relationship between GDP per capita and the immigration rate in Canada. In contrast to the tendency towards a positive effect of income on immigration in developed countries, the influence of income in the home countries on emigration is mixed. Agbola and Acupan (2008) confirmed the positive effect of per capita income on Overseas Filipino Workers (OFWs), albeit not significant. This finding supports a study of Mayda (2010) concerning the determinants of immigration in 14 Organization for Economic Co-operation and Development (OECD) countries from 1980 to 1995. The effect of per worker GDP in the home country on emigration is generally positive and not significant. This implies that workers who migrate internationally are not very poor because the very poor people cannot afford the migration cost (Hatton and Williamson, 2002).

The negative influence of income in the home countries on emigration is reported in some studies. Ahmad et al. (2008) proved the negative effect of the real wage rate in Pakistan on emigration. Based on the data on immigrants from 101 countries in the USA from 1996 to 2000, Melkumian (2004) confirmed that GDP per capita in the home country negatively and significantly determines immigration in the USA. He concluded that the higher GDP per capita in the home country reduces the incentive for migration as well as increases the 
number of people who will be able to migrate. Similarly, Karemera et al. (2000) also concluded that increasing income in the home country significantly reduces international labour migration in the USA. The dual labour market theory emphasizes the strong demand for foreign labour especially in the lowest hierarchy of jobs in the host country as a pull factor of labour migration (Piore, 1979). Unemployment in the host country may indicate labour market conditions whereby the low unemployment rate reflects high employment opportunities in such a country. Studies by Karemera et al. (2000) in the USA and by Jennisen (2002) in Switzerland show the negative effect of unemployment in these host countries on immigration. Jennisen (2002) concluded that the high unemployment rate in the host countries is less likely to attract immigrants who do not have sufficient skills to compete in the host country labour market. This is different from the high-skilled immigrants who disregard the high unemployment rate in the host country, as found in Norway (Jennisen, 2002) and Canada (Karemera et al., 2000). Unemployment in the home country is another push factor of emigration. Boca and Venturini (2003) argued that the migration of Italians abroad is mainly due to the high unemployment rate in Italy. The high unemployment rate in the Philippines (Agbola and Acupan, 2008) and Pakistan (Ahmad et al., 2008) also pushes emigration in these countries. Unemployment, however, does not necessarily have a positive effect on emigration. Pederson et al. (2004) revealed the negative effect of unemployment in the low-income countries on immigration in the OECD countries, which reflects the obstacle of poverty for emigration.

Income, unemployment and international labour migration do not necessarily have a long-run relationship. However, studies on this issue tend to concentrate on the host country of migrant workers. Feridun (2007) investigated the causal relationship between immigration, GDP per capita and unemployment in Sweden by using the autoregressive distributing lag (ARDL) bounds testing approach. The results show that all the variables in the model are cointegrated. There is a long-run bidirectional causality between immigration and GDP per capita and unidirectional causality from unemployment to immigration. In another study, Feridun (2004) proved no long-run relationship among GDP per capita, unemployment and international migration in Finland. Gonzalez-Gomez and Giraldez (2011) confirmed that economic growth and international migration are cointegrated in Germany. This is not however the case for Switzerland. In Germany, the GDP per capita and number of foreigners per head have a bi-directional causality in the long-run.

\section{Methodology}

This study examines the model whereby the Indonesian migrant workers in Malaysia are a function of two factors: the push factors in Indonesia and the pull factors in Malaysia. The Indonesian migrant workers model is formulated as follows:

$\mathrm{FWI}=f(\mathrm{GDPCi}, \mathrm{UNPi}, \mathrm{GDPm}, \mathrm{UNPm})$

Where GDPC denotes Gross Domestic Product per capita while GDP denotes Gross Domestic Product; UNP denotes the number of economically active population who are job seekers; FWI denotes the number of registered foreign workers from Indonesia in Malaysia; and $\mathrm{i}$ and $\mathrm{m}$ refer to Indonesia and Malaysia, respectively. Both GDPC and GDP are in US dollar and used to measure income. This study employs GDP instead of GDPC for Malaysia because the use of GDPC in the model shows no short-run as well as long-run relationship between the variables in the model.GDP per capita and unemployment in Indonesia represent push factors while GDP and unemployment in Malaysia represent pull factors. The push and pull factors are independent variables while FWI is a dependent variable. Secondary data is used in this study. GDP per capita and GDP data are published by the International Monetary Fund (IMF) (2012), unemployment data was obtained from the Asian Development Bank (ADB) publication (2012) while the Indonesian migrant workers data was published by the Ministry of Home Affairs Malaysia. Quarterly data from 1999 up to 2010 are utilized and the data have been transformed in natural log form.

The VAR approach is utilized in this study. Before conducting the cointegration test, the Kwiat kwoski, Phillips, Schmidt and Shin (KPSS) (1992) test was carried out to detect the order of integration for each variable in the model. The KPSS proposed a null hypothesis of mean stationary against the alternative hypothesis of a unit root. Non-stationary variables having the same integration order have the possibility of 
having a long-run relationship. The long-run relationship among the five variables in the model is examined by utilizing the Johansen and Juselius (1990) cointegration test. The hypothesis in the Trace test is at most $r$ cointegrating vectors while in the Maximum Eigen value test it is $r$ cointegrating vectors. Johansen and Juselius (1990) provide critical values for both statistics. The Schwarz Information Criterion (SIC) was used to select the optimal lag length.

The long-run cointegration equation is presented as follows:

$\mathrm{y}_{\mathrm{t}}=\beta \mathrm{x}+\mathrm{u}_{\mathrm{t}} \quad($ Eq.2)

Where $y$ denotes a normalized variable, $x$ a vector of the other variables in the model including the constant, and $\beta$ is a vector of long-run parameters.

In the event of cointegration, the Granger causality test (Granger, 1988) is conducted in the Vector Error Correction Model (VECM) approach (Masih and Masih, 1996). The equation is written as follows:

$\Delta \mathrm{z}_{\mathrm{t}}=\alpha+\beta(\mathrm{L}) \Delta \mathrm{z}_{\mathrm{t}-1}+\lambda \mathrm{u}_{\mathrm{t}-1}+\varepsilon_{\mathrm{t}} \quad$ (Eq.3)

Where $\mathrm{z}$ is a vector of the variables in the equation, $\alpha$ is a vector of constant terms, $\beta(L)$ is the matrix for the polynomial in the lag operator $L, u$ the error correction term and $\lambda$ is a vector of long-run speed of adjustment coefficients. The VECM treats all variables as potentially endogenous thereby enabling evaluation of the Granger causality in the long-run and the short-run for each independent variable.

\section{Results and Discussion}

The results of the KPSS unit root test (Table 3) show that all levels of Hoare rejected whether with intercept and with trend and intercept (FWI), intercept only (GDPCi, GDPm and UNPm), or trend and intercept only (UNPi). The results confirm that all the variables have a unit root. Since all the variables have a unit root, the cointegration test can be carried out.

Table 3: The Results of KPSS Unit Root Test

\begin{tabular}{lllll}
\hline \multirow{2}{*}{ Variables } & \multicolumn{2}{c}{ Level } & \multicolumn{2}{c}{ 1st difference } \\
\cline { 2 - 5 } & \multicolumn{1}{c}{ Intercept } & $\begin{array}{c}\text { Trend and } \\
\text { Intercept }\end{array}$ & \multicolumn{1}{c}{ Intercept } & $\begin{array}{c}\text { Trend and } \\
\text { Intercept }\end{array}$ \\
\hline FWI & $0.496819^{* *}$ & $0.223689^{*}$ & $0.853459^{*}$ & 0.089571 \\
GDPCi & $0.822537^{*}$ & 0.133929 & 0.143195 & 0.141930 \\
UNPi & 0.308971 & $0.220256^{*}$ & $0.774401^{*}$ & 0.058024 \\
GDPm & $0.808480^{*}$ & 0.139345 & 0.251414 & $0.163132^{* *}$ \\
UNPm & $0.554967^{* *}$ & 0.107075 & 0.343555 & 0.101193 \\
\hline
\end{tabular}

Notes: Asterisks $\left({ }^{*}\right)$ and $\left({ }^{* *}\right)$ denote significant at the 1 and 5 per cent levels, respectively

By using lag 1 based on the SIC selection, only the Trace statistic results show that income and unemployment in Indonesia and Malaysia and the Indonesian migrant workers in Malaysia have a long-run relationship (Table 4). This finding supports the studies in some host countries, such as Sweden (Feridun, 2007) and Germany (Gonzalez-Gomez and Giraldez, 2011). 
Table 4: The Results of Johansen-Juselius Cointegration Test

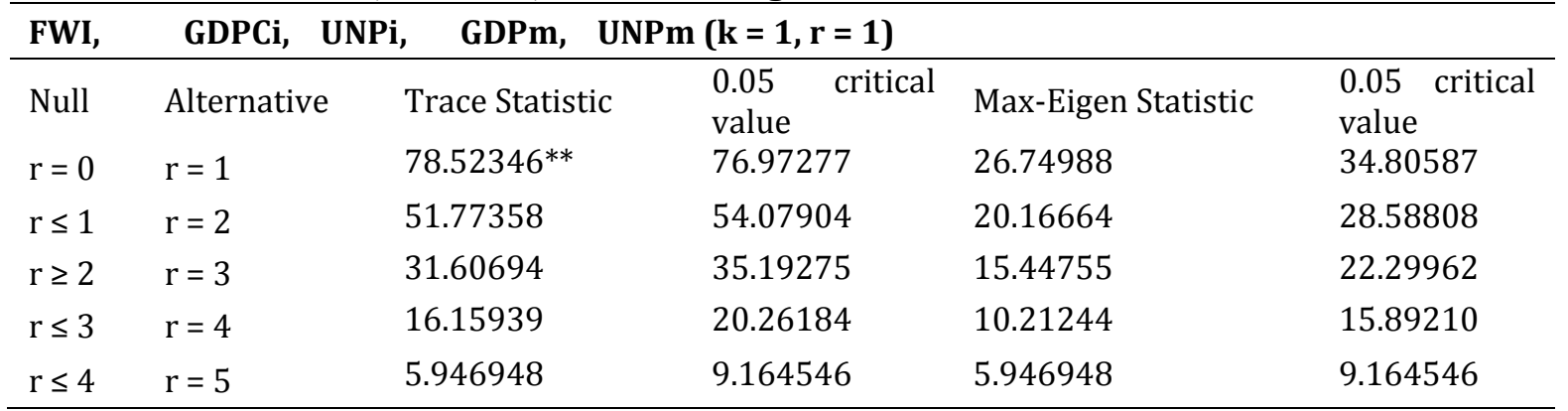

Notes: The $k$ is the lag length, $r$ is the number of cointegrating vectors, and asterisk $\left.{ }^{* *}\right)$ denotes significant at the 5 per cent level.

The result of the VECM (Table 5) indicates that short-run causality is not found in all variables in the model. This means that income and unemployment in both countries do not have any short-run impact on the supply of Indonesian migrant workers to Malaysia. Moreover, the Indonesian migrant workers in Malaysia (FWI) are the only equation that is significant in the long-run because the coefficient of ECT is negative, less than 1 and significant. This implies that in the long-run, income and unemployment, both in Indonesia and Malaysia, cause the Indonesian migrant workers in Malaysia. Similarly, Feridun (2007) reported that unidirectional causality runs from unemployment to immigration in Sweden.

Table 5: The Results of VECM

\begin{tabular}{|c|c|c|c|c|c|c|c|}
\hline \multirow{2}{*}{$\begin{array}{l}\text { Dependent } \\
\text { Variables }\end{array}$} & $\Delta$ FWI & $\triangle$ GDPCi & $\Delta \mathbf{U N P i}$ & $\Delta$ GDPm & $\Delta \mathrm{UNPm}$ & \multicolumn{2}{|c|}{$\begin{array}{lll}\text { Error } & \text { Correction } & \text { Term } \\
\text { (FCT) }\end{array}$} \\
\hline & \multicolumn{5}{|c|}{ Chi square statistics [p value] } & Coefficient & t-ratio \\
\hline \multirow{2}{*}{ FWI } & & 3.069578 & 0.960665 & 0.979332 & 3.900215 & \multirow{2}{*}{-0.342785} & \multirow{2}{*}{$-2.02260^{*}$} \\
\hline & & {$[0.2155]$} & {$[0.6186]$} & {$[0.6128]$} & [0.1423] & & \\
\hline \multirow{2}{*}{ GDPCi } & 0.485055 & & 0.370421 & 0.167884 & 1.526964 & \multirow{2}{*}{-0.139727} & \multirow{2}{*}{-0.62796} \\
\hline & {$[0.7846]$} & & {$[0.8309]$} & [0.9195] & {$[0.466]$} & & \\
\hline \multirow{2}{*}{ UNPi } & 1.696309 & 0.174446 & & 0.434109 & 0.477091 & \multirow{2}{*}{0.132737} & \multirow{2}{*}{2.07270} \\
\hline & {$[0.4282]$} & {$[0.9165]$} & & [0.8049] & {$[0.7878]$} & & \\
\hline \multirow{2}{*}{ GDPm } & 0.871607 & 0.251395 & 0.707852 & & 1.642637 & \multirow{2}{*}{-0.102196} & \multirow{2}{*}{-0.50530} \\
\hline & {$[0.6467]$} & [0.8819] & [0.7019] & & {$[0.4399]$} & & \\
\hline \multirow{2}{*}{ UNPm } & 2.238639 & 0.318783 & 1.395322 & 0.239536 & & \multirow{2}{*}{0.216972} & \multirow{2}{*}{1.62364} \\
\hline & {$[0.3265]$} & [0.8527] & [0.4977] & [0.8871] & & & \\
\hline
\end{tabular}

Notes: Asterisk $(*)$ denotes significant at the 1 per cent level.

Furthermore, the results of the normalized equation indicate that GDP and unemployment in Indonesia and Malaysia determine the Indonesian migrant workers in Malaysia significantly and the signs of the coefficient for Indonesia and Malaysia are contradictory.

The results of normalized equation

FWI $=-3.160590+0.745452$ GDPCi +3.292671 UNPi- 0.706120 GDPm- 0.622930 UNPm

$[3.25842]^{*}[15.6017]^{*}[-2.29523]^{*}[-2.85924]^{*}$

Note: Asterisk $(*)$ denotes significant at the 1 per cent level. Value in the parenthesis is t statistics. 
Income and unemployment in Indonesia positively act as push factors to the Indonesian migrant workers in Malaysia. This means that higher income and unemployment in Indonesia will be followed by a greater supply of Indonesian migrant workers to Malaysia. The positive effect of income in Indonesia on the Indonesian migrant workers in Malaysia confirms the study of Agbola and Acupan (2008) in the Philippines, and Mayda (2010) in the home countries of immigrants in OECD countries. Meanwhile the positive influence of unemployment on emigration also supports the findings in Indonesia (Said et al., n.d.), the Philippines (Agbola and Acupan, 2008) and Pakistan (Ahmad et al., 2008). Furthermore, income and unemployment in Malaysia act as pull factors to the Indonesian migrant workers to this country. The negative influence of income in Malaysia on the Indonesian migrant workers is contradictory with the general findings in host countries, such as the countries in Western Europe (Jennisen, 2003), the USA (Karemera et al., 2000), Canada (Islam, 2007) and Malaysia (Said et al., n.d.). Meanwhile, lower unemployment in Malaysia increased the Indonesian worker supply to Malaysia. A similar finding is reported by Jennisen (2002) among low-skilled migrants from Portugal to Switzerland and by Karemera et al. (2000) among immigrants in the USA. The existing of dual labour market (Piore, 1979) may contribute to the negative influence of income and unemployment in Malaysia on Indonesian migrant workers in Malaysia. Increasing wages in the medium and high-skilled jobs in Malaysia will attract more local workers to work in these jobs, which, subsequently, will reduce the demand for migrant workers. However, the strong demand for low-skilled workers which offer low wages will attract Indonesian migrant workers supply to Malaysia. The low-paid job in Malaysia is still attractive for the Indonesian migrant workers due to the lower value of the rupiah compared to the Malaysian ringgit.

\section{Conclusion}

This study examined the long-run relationship among the push factors represented by income and unemployment in Indonesia and the pull factors represented by income and unemployment in Malaysia on the Indonesian migrant workers in Malaysia. The causality between the push and pull factors and the Indonesian migrant workers in Malaysia was also tested. The study has proven that the pull and push factors and the Indonesian migrant workers in Malaysia are cointegrated while the pull and push factors cause the Indonesian migrant workers in Malaysia in the long-run.Moreover the study examined the effect of the pull and push factors on the Indonesian migrant workers in Malaysia. The significant opposite effect of push and pull factors on the Indonesian migrant workers in Malaysia has been found. The push and pull factors determine the Indonesian migrant workers supply to Malaysia positively and negatively, respectively. Currently, Malaysia has a higher income and a lower unemployment than Indonesia which may encourage the supply of Indonesian migrant workers to Malaysia. The finding indicates that although this is true for the case of low unemployment, it is not true in the case of high income. The positive effect of income in Indonesia and the negative effect of income in Malaysia on Indonesian migrant workers in Malaysia contradict with the popular belief both in Indonesia and Malaysia. The finding indicates that Indonesian migrant workers in Malaysia are not very poor because the higher the income in Indonesia, the greater the probability of Indonesians working in Malaysia. Moreover, the higher income in Malaysia will reduce instead of increase the Indonesian migrant workers in Malaysia thereby indicating the greater demand for local workers than the foreign workers in a relatively higher paid job. In other words ${ }_{2}$ Indonesian migrant workers are less likely to deprive job opportunities for the local workers. Hence, the neo-classical economic theory on migration especially in regard to income is not entirely applicable to the situation of Indonesian migrant workers in Malaysia.

The dual labour market theory may help to explain the situation in Malaysia. Malaysia's dual labour market needs relatively medium- and high-skilled labour which is most likely supplied by local workers who prefer high-paid job. The labour market also needs low-skilled workers with low payment which are most likely supplied by Indonesian migrant workers. As long as dual labour market exists and demand for low-skilled workers is strong in Malaysia, Indonesian migrant workers will keep coming to Malaysia especially if the Malaysian ringgit is stronger compared to the Indonesian rupiah. In the light of the abovementioned findings, several recommendations may be made. Since the issue of migrant workers is sensitive for both Indonesia and Malaysia, it is recommended that the governments of both countries should have a comprehensive policy on this issue. The Indonesian government not only has to create jobs but also has to ensure that wages in 
Indonesia enable its workers to have a better living standard. In addition, the government also needs policies which will strengthen the value of the Indonesian rupiah over ringgit which will reduce the difference on the real value of wages between the two countries. It is also recommended that the Malaysian government may consider reallocating the firms employing many Indonesian migrant workers to Indonesia as a form of foreign direct investment outflow to Indonesia. Minimizing the number of foreign workers will reduce the problems faced by the Malaysian government. There are some limitations to this study. One of the limitations is the limited number of observations. The use of GDP per capita of Indonesia and GDP of Malaysia as a representation of income may also be inaccurate. These limitations require caution in interpreting the findings of the study.

Acknowledgement: The earlier version of this paper was presented at the International Conference on Multidisciplinary Research (iCMR 2012), Universiti Sains Malaysia (USM), Penang. This paper was written based on a part of research under the Fundamental Research Grant Scheme, Ministry of Higher Education (MOHE), Malaysia.

\section{References}

ADB (Asian Development Bank). (2012). Key indicators for Asia and the Pacific 2012 (Indonesia). Retrieved from https://sdbs.adb.org/sdbs/index.jsp

Agbola, F. W. \& Acupan, A. B. (2008). What drives international labour migration in the Philippines? Paper presented at the EABR \& TLC Conference, Rothenburg, Germany.

Ahmad, N., Hussain, Z., Sial, M. H., Hussain, I. \& Akram, W. (2008). Macroeconomic determinants of international migration from Pakistan. Pakistan Economic and Social Review, 46(2), 85-99.

Ahmad, L. (2012). Labour migration: Malaysia as a receiving country. Paper presented at the 2nd ADBI-OECD roundtable on labour migration in Asia, Tokyo, Japan.

BNP2TKI (National Authority for the Placement and Protection of Indonesian Overseas Workers). (2012). Data on Indonesian migrant workers. Retrieved from http://www.bnp2tki.go.id/.

Boca, D. D. \& Venturini, A. (2003). Italian migration. IZA Discussion Paper No. 938, Bonn, Germany.

Feridun, M. (2007). Immigration, income and unemployment: An application of the bounds testing approach to cointegration. The Journal of Developing Areas, 41(1), 37-49.

Feridun, M. (2004). Does immigration have an impact on economic development and unemployment? Empirical evidence from Finland (1981 - 2001). International Journal of Applied Econometricsand Quantitative Studies, 1(3), 39-60.

Gonzalez-Gómez, M. \& Giráldez, M. (2011). The causality between economic growth and immigration in Germany and Switzerland. The Economic and Social Review, 42(3), 271-287.

Granger, C. W. J. (1988). Some recent development in the concept of causality. Journal of Econometrics, 39, 199 $-211$.

Hatton, T. J. \& Williamson J. G. (2002). What fundamentals drive world migration? NBER Working Paper No. 9159, Cambridge, United Kingdom.

IMF (International Monetary Fund). (2012). World economic outlook database September 2011. Retrieved from http://www.imf.org/external/data.htm\#data.

IOM (International Organization for Migration). (2010). International migration and migrant workers' remittances in Indonesia. Makati City: IOM.

Islam, A. (2007). Immigration unemployment relationship: the evidence from Canada. Australian Economic Papers, 46(1), 52-66.

Jennissen, R. (2003). Economic determinants of net international migration in Western Europe. European Journal of Population, 19(2), 171-198.

Jennissen, R. (2002). Economic determinants of international labour migration in the EU/EFTA region 19851999. Paper presented at the 42nd Congress of the European Regional Science Association, European Regional Science Association (ERSA), Dortmund,Germany.

Johansen, S. \& Juselius, K. (1990). Maximum likelihood estimation and inference on cointegration with application to the demand for money. Oxford Bulletin of Economics and Statistics, 52, $169-210$.

Kanapathy, V. (2008). International migration statistics and data sources - Malaysia. Asian and Pacific Migration Journal, 17(3-4), 335-347. 
Karemera, D, Oguledo, V. I. \& Davis, B. (2000). A gravity model analysis of internationalmigration to North America. Applied Economics, 3 (13), 1745-1755.

Kassim, A. (2000). Indonesian immigrant settlements in peninsular Malaysia. SOJOURN, 15(1), 100-122.

Kwiatkowski, D., Phillips, P. C. B., Schmidt, P. \& Shin, Y. (1992). Testing the null hypothesis of stationarity against the alternative of a unit root. Journal of Econometrics, 54, 159-178.

Malaysian Digest. (2012). 480,995 Illegal Immigrants Legalized Under 6P. Retrieved from [http://www.malaysiandigest.com/news/44243-480995-illegal-immigrants-legalized-under6p.html] 16 May.

Mantra, I. B. (2000). Indonesian labour mobility to Malaysia: a case study: East Flores, West Lombok, and the Island of Bawean. InSukamdi, A. Haris, P. Brownlee (Eds.), Labour migration in Indonesia: Policies and practices. Jogyakarta: Population Studies Center Gadjah Mada University.

Masih, A. M. M. \& Masih, R. (1996). Empirical tests to discern the dynamic causal chain in macroeconomic activity: new evidence from Thailand and Malaysia based on a multivariate cointegration/vector error-correction modeling approach. Journal of Policy Modeling, 18(5), 531-560.

Massey, D. S., Arango, J., Hugo, G., Kouaouci, A., Pellegrino, A. \& Taylor, J.E. (1993). Theories ofinternational migration: A review and appraisal. Population and Development Review, 19(3), 431-466.

Mayda, A. M. (2010). International migration: a panel data analysis of the determinants of bilateral flows. Journal of Population Economic, 23(4), 1249-1274.

Mei, L. (2006). Indonesian labor migrants in Malaysia: a study from China. Institute of China Studies (ICS) University of MalayaWorking Paper No. 11,Kuala Lumpur, Malaysia.

Melkumian, A, V. (2004). A gravity model of legal migration to the United States. Western Illinois University Working Paper, Illinois, the USA.

Ministry of Home Affairs. (n.d.). Number offoreign workers in Malaysia by countries and sectors. Retrieved from http://www.epu.gov.my/populationandlabourforce.

Nasution, M. A. (2000). International migration in South East-Asia: A case study of Indonesian migrant workers in the Malaysian Peninsula. InSukamdi, A. Haris, P. Brownlee (Eds.), Labour migration in Indonesia: Policies and practices. Jogyakarta: Population Studies Center Gadjah Mada University.

Pedersen, P. J., Pytlikova, M. \& Smith, N. (2004). Selection or network effects? Migration flows into 27 OECD countries, 1990-2000. IZA Discussion Paper No. 1104, Bonn, Germany.

Piore, M. J. (1979). Birds of passage: Migrant labor in industrial societies. Cambridge: Cambridge University Press.

Said, S. M., Said, F. \& Harahap, S. R. S. (n.d.). Migrasi antarabangsa: Penghijrahan buruh Indonesia ke Malaysia [International migration: Indonesian migrant workers in Malaysia]. Faculty of Economics and Management, University of Malaya. Kuala Lumpur, Malaysia. Retrieved from http://www.mohr.gov.my/ismk/pdf/ migrasi_2vol2.pdf

Widyawati, N. (2008). Representations of migrant workers in Malaysian newspapers. In are we up to the challenge?: current crises and the Asian intellectual community. The Work of the 2005/2006 API Fellows, 222, Bangkok, Thailand.

$\mathrm{Wu}, \mathrm{T}$. (2006). The role of remittances in crisis: an Aceh research study. HPG Background Paper, London, United Kingdom.

Yusuf, B. M. (2008). Occupational mobility among Indonesian immigrants with special reference to Acehnese. Master Thesis. International Islamic University, Kuala Lumpur, Malaysia. Retrieved from International Islamic University Malaysia Digital Theses (http://lib.iium.edu.my /mom2/cm/content/view/view.jsp 